\title{
Theoretical Perspectives Underlying the Application of Cooperative Learning in Classrooms
}

\author{
Van Dat Tran ${ }^{1}$ \\ ${ }^{1}$ Faculty of Education, AnGiang University, Vietnam, AnGiang, Vietnam \\ Correspondence: Van Dat Tran, Faculty of Education, An Giang University, Vietnam. E-mail: tvdat@agu.edu.vn
}

Received: September 3, 2013

Accepted: October 17, 2013

Online Published: October 18, 2013

doi:10.5430/ijhe.v2n4p101

URL: http://dx.doi.org/10.5430/ijhe.v2n4p101

\begin{abstract}
Cooperative learning has been the centre of worldwide attention because it has been shown to have strong effects on student learning, as well as other positive outcomes. Although the academic, social, affective and psychological outcomes of students taught by cooperative learning are more positive compared with students taught by the traditional teaching method, there are many misunderstandings and disagreements about the reasons why. This paper investigated this question and suggested a range of theoretical models to explain the effectiveness of cooperative learning. These theoretical perspectives include the social interdependence theory, the cognitive perspective, and the social learning theory, all of which contribute to the theory of learning known as constructivism.
\end{abstract}

Keywords: Cooperative learning, Social interdependence theory, Cognitive perspective, Social learning theory, Constructivism

\section{Introduction}

\subsection{Definition of cooperative learning}

The way we teach and learn in modern educational environments has been transformed through the advent of cooperative learning (Johnson \& Johnson, 2009). Different researchers have different definitions of cooperative learning. For example, Johnson and Johnson (1990c) define cooperative learning as "the instructional use of small groups so that students work together to maximize their own and one another's learning” (p.69). On the other hand, Sharan (1994) defines it as "a group-centred and student-centered approach to classroom teaching and learning" (p.336), while Slavin (2011) refers to cooperative learning as "instructional methods in which teachers organize students into small groups, which then work together to help one another learn academic content” (p.344). Although researchers have not used the same official definition of this term, all of them refer to cooperative learning as a "set of methods in which students work together in small groups and help one another to achieve learning objectives" (Johnson \& Johnson, 2009, p.69). In other words, cooperative learning is the pedagogy within which students are active constructors of knowledge in the learning process instead of passive receivers of any given knowledge (Liang, 2002). There are three main types of cooperative learning groups, namely informal cooperative learning groups, formal cooperative learning groups, and cooperative based groups (Johnson \& Johnson, 2008). Informal cooperative learning, lasting from a few minutes to one class period, are short-term and ad-hoc groups in which students are required to work together to achieve a shared learning goal. Informal cooperative learning may be used to help students engage in the learning task, and focus their attention on the material they are to learn through focused-pair discussions before and after a lecture. Cooperative based groups usually last a semester or an academic year, or even several years. They are long-term and heterogeneous learning groups with committed relationships, in which students support one another to complete assignments and make academic progress. Formal cooperative learning groups last from one class period to several weeks. These are cooperative learning groups in which students work together to complete the learning tasks assigned and achieve shared learning goals.

\subsection{Basic elements of cooperative learning}

Conducting cooperative learning does not mean that we simply let students sit next to each other at the same desk and ask them to do their own tasks (Gillies, 2003). Johnson \& Johnson (1998) claim that "placing people in the same room, seating them together, telling them that they are a cooperative group, and advising them to 'cooperate', does not make them a cooperative group" (p.15). A cooperative learning environment will exist if groups are structured in such a way that group members co-ordinate activities to facilitate one another's learning (Ballantine \& Larres, 2007). In order to 
engage students in learning, five elements: positive interdependence, face-to-face interaction, individual accountability, interpersonal \& social skills, and group processing, must be present in the cooperative classroom (Johnson \& Johnson, 2008).

\section{Positive interdependence}

Positive interdependence is the first essential element of cooperative learning. Learning situations are not cooperative if students are arranged into groups without positive interdependence (Johnson \& Johnson, 2009). Positive interdependence means that in cooperative learning situations, students are required to work together as a cohesive group to achieve shared learning objectives (Yager, 2000; Jensen, Moore \& Hatch, 2002). In the process, students must be responsible for their own learning and for the success of other group members' learning (Slavin, 2011). In other words, students must ensure that other members in their group complete the tasks and achieve the academic outcomes. The lesson will not be cooperative if students do not "swim together" in the group learning activities (Johnson \& Johnson, 2008). If group members are not dependent on each other and fail to have shared interest in working together to accomplish the tasks, the success of the group will decrease (Ballantine \& Larres, 2007). In other words, if one group member fails to complete his or her learning task, all the other group members will suffer the consequences of that member's poor presentation. More specifically, the achievement of the group depends on that of each member (Kose, Sahin, Ergun, \& Gezer, 2010). All group members must be cooperative in learning activities and are responsible for the success or failure of each member in their group (Jensen et al., 2002). Hence, positive interdependence needs to be constructed in cooperative learning groups to help students work and learn together. Positive interdependence may be structured through the assignment of complementary roles (Thomas 1957), group contingencies (Skinner 1968), dividing information into separate pieces (Aronson et al. 1978) or divisions of labor (Johnson \& Johnson, 2008). To ensure interdependence operates effectively, the roles of readers, summarizers, examiners, note-takers and encouragers in learning groups should be assigned (Knight \& Bohlmeyer, 1990). Specifically, readers read lessons and problems aloud for other group members; summarizers summarize the lessons; note-takers write the group's decisions or reports; and encouragers stimulate all group members to participate in discussion and exchange their opinions and feelings. Many research studies demonstrate the positive effects of positive interdependence on productivity and achievement. Positive interdependence produces higher achievement and productivity (Hwong, Caswell, Johnson \& Johnson, 1993; Johnson \& Johnson, 2008). One group member's performance affects the success of other group members and tends to create "responsibility forces" that increase each member's efforts to achieve (Mesch, Johnson \& Johnson, 1988). Individuals achieve better under positive goal interdependence than when they worked individually (Johnson \& Johnson, 2005). When positive interdependence is clearly perceived, individuals realize that their efforts are required in order for the group to succeed so that it is not possible to get a "free-ride" (Kerr \& Bruun, 1983) and they have a unique contribution to make to the group's efforts. When members of a group do not see their efforts as necessary for the group's success, they may reduce their efforts (Kerr \& Bruun 1983). In contrast, when they perceive their potential contribution to the group as being unique, they increase their efforts (Harkins \& Petty 1982).

\section{Face-to-face promotive interaction}

The second element of cooperative learning is face-to-face promotive interaction. Positive interdependence results in reciprocal interaction among individuals, which promotes each group member's productivity and achievement. Promotive interaction occurs as individuals encourage and facilitate each other's efforts to accomplish the group's goals. In cooperative learning groups, students are required to interact verbally with one another on learning tasks (Johnson \& Johnson, 2008). As part of the cooperative learning condition, students are required to interact verbally with one another on learning tasks (Johnson \& Johnson, 2008), exchange opinions, explain things, teach others and present their understanding (Ballantine \& Larres, 2007). The quality of interaction depends on the group size, and frequency of students' cooperation on their learning tasks (Johnson \& Johnson, 1989). Hence, groups should be small when students begin learning together to help them develop cooperative learning skills. Moreover, the quality of group interaction depends on the academic level of all members in the group. The learning ability of all members in the group should be identified to help them to give feedback to and support one another in their learning. In addition, the quality of group interaction depends on the learning environment. If a positive learning environment is established, students in the cooperative group work and learn together effectively (Slavin, 2011). Many research studies characterize the positive effects of face-to-face interaction in cooperative classrooms. Such effects comprise providing group members with effective assistance (Johnson \& Johnson 1981, Webb \& Cullian, 1983), exchanging information and materials (Crawford \& Haaland, 1972; Johnson \& Johnson, 1974), providing group members with feedback for improving the subsequent performance of their assigned tasks and responsibilities (Ryan, 1982), challenging each other's conclusions (Johnson \& Johnson, 2007), advocating the exertion of effort to achieve mutual goals (Wicklund \& Brehm 1976), 
influencing each other's efforts to achieve the group's goals (Crombag, 1966), acting in trusting and trustworthy ways (Johnson \& Noonan, 1972), being motivated to strive for mutual benefit (Deutsch 1949; Johnson \& Johnson, 2005), and exploring different points of view (Johnson \& Johnson, 1989).

\section{Individual accountability}

The third essential element of cooperative learning is individual accountability. Individual responsibility means that students ask for assistance, do their best work, present their ideas, learn as much as possible, take their tasks seriously, help the group operate well, and take care of one another (Johnson, 2009).Positive interdependence is recognized to create "responsibility forces" that increase the individual accountability of group members for accomplishing shared work and facilitating other group members' work (Johnson \& Johnson, 2008). Individual accountability is considered as the degree to which the achievement of the group is dependent on the individual learning of all group members. If there is no individual accountability, one or two group members may do all the work while others do nothing. If the achievement of the group depends on the individual learning of each group member, then group members are motivated to ensure that all group members master the material being studied (Slavin, 1996). When group accountability and individual accountability exist in the group, the responsibility forces increase (Johnson \& Johnson, 2008). Group accountability exists when the overall performance of the group is assessed and the results are given back to all group members to compare against a standard of performance. Similarly, individual accountability exists when the performance of each individual member is assessed, the results are given back to the individual and the group to compare against a standard of performance, and the member is held responsible by group-mates for contributing his or her fair share to the group's success. The provision of information on the level of understanding of each student in the learning process can be considered as significant feedback, with the aim of defining the achievement level of each group member (Johnson \& Johnson, 1999). It is necessary for other members in the group to provide assistance if one or some group members cannot finish the assigned tasks (Kagan, 1985). In an examination of cooperative learning on student's learning, Hooper, Ward, Hannafin \& Clark (1989) found that cooperation resulted in higher achievement when individual accountability was structured rather than when it was not and argued that a lack of individual accountability may reduce feelings of personal responsibility. According to Yamarik (2007), in order to make cooperative activities in the group effective, each group member must be responsible for a defined part of the learning materials, and all group members must take individual accountability for their group members' achievement (Yamarik, 2007). All group members are required to ask for assistance, do their best work, present their ideas, learn as much as possible, do their tasks seriously, help the group operate well, and take care of one another (Robertson, 1990). Individual accountability may be constructed through keeping the size of the group small (Johnson, Johnson \& Holubec, 1994). The smaller the size of the group, the greater the individual accountability may be (Johnson \& Johnson, $1994 a ; b ; c)$. As the group size becomes smaller, group members tend to communicate more frequently, which may increase the amount of information utilized in arriving at a decision (Gerard, Wilhelmy \& Conolley, 1965; Messick \& Brewer, 1983). In contrast, as the group becomes larger and larger, members are less likely to see their own personal contribution to the group as being important to the group's chances of success (Kerr, 1989).

\section{Interpersonal and social skills}

Interpersonal and social skills are the fourth essential element of cooperative learning. In reality, students cannot work effectively if socially unskilled students are arranged into one group (Johnson \& Johnson, 2006). If basic learning skills on cooperative interaction are not taught, group members cannot work together effectively to finish their tasks (Sharan, 1990). Cooperative learning, compared with individualistic or competitive learning, is more complex because it requires students to engage in learning tasks and work together (Johnson \& Johnson, 1990b; Ballantine \& Larres, 2007). Therefore, social and interpersonal skills, such as listening attentively, questioning cooperatively and negotiating respectfully need be taught, to help students cooperate effectively in the group (Killen, 2007). In addition, each group member should know how to manage the group, how to make decisions and how to solve conflicts that arise among group members. If these skills are not taught, cooperative learning activities are rarely successful (Slavin, 1996). Interpersonal and social skills can be taught using techniques such as role playing, and modeling in group activities (Slavin, 2011). Group members must have, or be taught, the interpersonal and small group skills needed for high quality cooperation, and be motivated to use them. To coordinate efforts to achieve mutual goals, participants must: (a) get to know and trust each other; (b) communicate accurately and unambiguously; (c) accept and support each other; and (d) resolve conflicts constructively (Johnson \& Johnson, 2009). In their studies on the long-term implementation of cooperative teams, Lew and Mesch (Lew, Mesch, Johnson \& Johnson, 1986; Mesch et al., 1988) found that the combination of positive goal interdependence, a contingency for high performance by all group members, and a social skills contingency, promoted the highest achievement and productivity. Archer-Kath, Johnson \& Johnson (1994) found that giving participants individual feedback on how frequently they engaged in targeted social skills was more effective 
in increasing participants' achievement than group feedback. Thus, the more socially skillful participants are, the more social skills are taught and rewarded, and the more individual feedback participants receive on their use of the skills, the higher the achievement and productivity of the cooperative groups tends to be. Not only do social skills promote higher achievement, they contribute to building more positive relationships among group members. For example, Putnam, Rynders, Johnson \& Johnson (1989) demonstrated that when participants were taught social skills, observed, and given individual feedback as to how frequently they engaged in the skills, their relationships became more positive.

\section{Group processing}

The fifth essential element of cooperative learning is group processing. Group processing is defined as reflecting on a group session to help students: (1) describe what member actions were helpful and unhelpful; and (2) make decisions about what actions to continue or change (Johnson et al., 1994, p.33). Group processing helps improve the effectiveness of the members in contributing to the shared efforts to achieve the group's goals via reflection on the learning process (Yamarik, 2007). In other words, the purpose of group processing is to clarify and improve the effectiveness of the members in contributing to the joint efforts to achieve the group's goals. There are two levels of processing: small-group and whole class. At the level of small-group processing, teachers should allocate some time at the end of each class for cooperative groups to process how effectively members worked together. Such group processing: (i) enables cooperative groups to maintain good relationships among group members; (ii) facilitates cooperative skills of group members; (iii) examines the group's tasks and gives students feedback on their participation; (iv) examines students'knowledge on their own learning parts; and (v) celebrates the success of the small group, and reinforces group members' positive behaviors (Johnson et al., 1994, p.33). In addition to small-group processing, teachers should engage in whole-class processing by observing the groups, giving feedback to each group, and sharing observation results in the class through a whole-class processing session at the end of the class period (Johnson et al., 1994).

Some research studies claim that group processing in cooperative learning groups has many positive effects. For example, in an examination of: (a) cooperative learning with group processing; (b) cooperative learning without any group processing; and (c) individualistic learning, Yager, Johnson, Johnson, \& Snider (1986) indicate that the participants in cooperative groups with group processing achieved higher on academic achievement, and retention measures than did the participants experiencing the other two conditions. Similarly, Johnson, Johnson, Stanne, \& Garibaldi (1990) conducted a study comparing cooperation with no processing, cooperation with instructor processing, cooperation with instructor and participant processing, and individualistic efforts. The results show that all three cooperative conditions performed higher than the individualistic condition. The combination of instructor and participant processing resulted in greater problem solving success than the other cooperative conditions. In addition, in the examination of cooperative learning with group processing, Archer-Kath et al., (1994) found that group processing with individual feedback was more effective than group processing with whole group feedback in increasing: (a) achievement motivation, actual achievement, uniformity of achievement among group members, and influence toward higher achievement within cooperative groups; (b) participants' positive relationships and the quality of relationships between participants and the teacher, and; (c) self-esteem and positive attitudes toward the subject area.

In summary, if these basic elements of cooperative learning are included in cooperative learning groups, students achieve better, demonstrate superior learning skills (Johnson \& Johnson, 2008), and experience more positive relationships among group members, and between students and the teacher, and more positive self-esteem and attitudes toward the subject area (Slavin, 2011). Once these five elements are structured in cooperative settings, the roles of the teacher and students will be changed remarkably. The teacher becomes not the "sage on the stage", but "the guide on the side" (Johnson et al., 1994). The teacher's roles in a student-centered learning approach like cooperative learning are modeled by Hassard (1990) as follows:

[It] requires a conscious shift of perspective on the part of the teacher, away from authoritarian and toward coordination of cooperative actions and the facilitation of instruction. Teachers who have incorporated this philosophy into their classrooms orchestrate the students'activities and are masters in securing and creating well-designed, team-oriented tasks (p.ix).

As such, in the process of teaching, teachers are facilitators for students' learning, not persons who simply grant knowledge to students (Jolliffe, 2007). Instead of lecturing from the beginning of the lesson to the end, the teacher only needs to present to students the main points of the lesson, and then allow students to work in their groups. The teacher only intervenes when students need clarification of instructions, or when the teacher feels the need to question a group's answers, or praise students for a creative idea or the good use of social skills (Johnson et al., 1994; Lotan, 
2004). However, the teacher needs to be involved in the lesson appropriately in order to engage students in learning actively.

\section{Theoretical perspectives underlying cooperative learning}

\subsection{Social interdependence theory}

The social interdependence theory is relevant when each individual's goals are accomplished under the influence of the actions of others (Johnson \& Johnson, 2005). This perspective holds that students help each other learn because they care about the group and its members, and come to derive self-identity benefits from group membership (Slavin, 2011). A strong relationship has been found between cooperative learning and the social interdependence theory (Johnson \&Johnson, 2005). Levin (1948) proposes that states of tension motivate a person's behavior and as desired goals are perceived, actions are motivated by this tension to achieve the desired goals. Deutsch (1949) developed Levin's social interdependence theory by discussing the relationship between the goals of two or more individuals. According to Deutsch (1949), social interdependence may be both positive and negative. It may be positive when individuals work cooperatively to attain their shared goals, and it may be negative when individuals compete to claim who attained the goals. Each type of interdependence results in certain psychological processes. In cooperative situations, as argued by Deutsch (1949), the psychological processes associate with substitutability (the degree to which actions of one person substitutes for the actions of another person), inducibility (the openness to being influenced and to influencing others), and positive cathexis (the investment of psychological energy in objects outside of oneself, such as friends, family, and work) (Johnson \& Johnson, 2005, p.366). In competitive situations, the opposite psychological processes are highlighted, namely non-substitutability, negative cathexis and resistance to being influenced by others. A lack of social interdependence detaches an individual from others, thereby creating non-substitutability, cathexis only to one's own actions, and no inducibility, or resistance to completely shared goals. The basic premise of the social interdependence theory is that the way in which goals are structured determines how individuals interact, and interaction patterns create outcomes (Deutsch, 1949). Positive interdependence may result in promotive interaction, negative interdependence may result in oppositional interaction, and no interdependence may result in no interaction (Johnson \& Johnson, 2008). Promotive interaction is when individuals encourage and facilitate each other's efforts to complete tasks, and accomplish the group's goals. It comprises such variables as mutual help and assistance, exchange of needed resources, effective communication, mutual influence, trust, and constructive management of conflict. Oppositional interaction is when individuals discourage and obstruct each other's efforts to complete tasks and accomplish their goals. It comprises such variables as obstruction of each other's goal achievement efforts, tactics of threat and coercion, ineffective and misleading communication, distrust, and striving to win conflicts. No interaction is when individuals act independently without any exchange with each other while they work to accomplish their goals; individuals focus only on increasing their own productivity and achievement and ignore as irrelevant the efforts of others.

Findings from research (Johnson \& Johnson, 2009) show that the positive outcomes of social interdependence are identified as: effort to achieve, positive relationships and social support, and psychological health and self-esteem. For example, in a meta-analysis of 575 experimental studies conducted at different levels of education, in different subject areas, and in numerous countries, Johnson \& Johnson (1989) found that considerably greater performance is promoted by cooperation than by competitive or individualistic efforts. In cooperative situations, performance has been constructed in terms of achievement and productivity, long-term retention, on-task behavior, use of higher-level reasoning strategies, generation of new ideas and solutions, transfer of what is learned within one situation to another, intrinsic motivation, achievement motivation, continuing motivation to learn, and positive attitudes toward learning and school (Johnson \& Johnson, 2008). Similarly, in an examination of 158 studies, Johnson et al. (2002) found that cooperative learning conditions result in greater achievement than do competitive or individualistic conditions. In addition to achievement, positive relationships among individuals are more strongly promoted by cooperation than by competitive or individualistic efforts (Johnson \& Johnson, 2002). Positive relationships in cooperative situations include interpersonal attraction, liking, cohesion, esprit-de-corps, and social support (Johnson \& Johnson, 2008). Moreover, a strong relationship was found between cooperation and psychological health (Johnson \& Johnson, 1989; 2002). Psychological health refers to the ability (cognitive capacities, motivational orientations, and social skills) in which cooperative relationships among individuals are developed and maintained to succeed in achieving goals (Montagu, 1966; Horney, 1937; Johnson 2003). The social interdependence theory provides a foundation for the practice of cooperative learning. This theory is compatible with the nature of cooperative learning in which knowledge and skills are constructed through mutual interaction among participants. Therefore, in the process of applying cooperative learning, interactive tasks and cooperative lessons should be designed and applied in in the classrooms to help students work and learn together to achieve shared goals. 


\subsection{Cognitive perspective}

Cognitive theory explores how the process of thinking and learning occurs by considering the inside of the human mind. Cognitive perspectives held by researchers are that mutual interaction between students with "the mental processing of the information rather than with motivations" (Slavin, 1996, p.48) will improve students' academic achievement. The two perspectives: cognitive development and elaboration are discussed below to comprehensively examine their effects on student learning.

\section{Cognitive developmental perspective}

The cognitive development perspective arose from the work of Piaget (1926) and Vygotsky (1978). A basic assumption of the cognitive development perspective driven by their theories, together with those of their colleagues, is that reciprocal interaction among children around suitable academic tasks creates growth in the knowledge of concepts and critical skills (Slavin, 2011). Vygotsky's notion of the Zone of Proximal Development (ZPD) is meaningful to learning. Such learning happens through interaction with each other in the ZPD. Vygotsky defines the ZPD as:

the distance between the actual developmental level as determined by independent problem solving and the level of potential development as determined through problem solving under adult guidance or in collaboration with more capable peers. (Vygotsky, 1978, p.86).

Vygotsky stresses the importance of cooperative activities and argues that the development of children is promoted by cooperative activities. In his view, cooperative activities among children promotes growth because children of the same age work in one another's ZPD and model behaviors, which is more effective than children working individually (Slavin, 2011). Vygotsky (1978) argues that "functions are first formed in the collective in the form of relations among children and then become mental functions for the individual... Research shows that reflection is spawned from argument" (p.47). In the learning process, a crucial element is that it must stimulate inside growth that only happens when a child joins, in cooperation and interaction, with his or her peers (Vygotsky, 1978). In addition, knowledge is a "societal product" because cognitive processes are "the outcomes of cultural and social interactions" (Vygotsky, 1978, p.84), and a cause of learning must be social interaction. To stress the importance of the role of social interaction, Vygotsky (1978) claims that "individual learners first learn through individual to individual social interaction and then knowledge is individually internalized" (p.84). Hence, social interaction needs to be encouraged in the process of learning because if social interaction or group interaction does not exist, students may not reach any shared goals or achievement (Slavin, 1990; Johnson \& Johnson, 2008). Learners construct knowledge socially, based on their current or past knowledge, through social interaction rather than by observing it objectively (Vygotsky, 1978). If reciprocal interaction exists in the learning environment, the two factors of affinity and support among participants in the learning process will make students feel that they are an important part of this learning environment (Liang, 2002). In traditional classes, these conditions rarely exist because there is little reciprocal interaction between students. Vygotsky's notion creates a solid basis for modern trends in the practice of teaching and learning. This theory emphasizes reciprocal interaction in learning; therefore, it makes the learning environment more natural and interactive (Beck \& Chizhik, 2008).

Piaget (1926) supports the cognitive developmental perspective, and argues that knowledge, values, regulations, morals and systems of symbols may only be learned effectively through interaction among participants. If Vygotsky's theory considers that learning and its results occur from social interaction, and all contribute to cognitive development, Piaget's theory considers that cognitive development occurs from social interaction, and all contribute to learning and its results. Piaget's developmental theory emphasizes the involvement and participation of learners in the learning and thinking process. In the learning process, learners construct and reconstruct knowledge by themselves. Piaget (1926) claims that an active discovery learning environment should be encouraged to provide students with opportunities for assimilation and accommodation. This means that learners will appropriate the new knowledge and then assimilate it to their existing knowledge. If the new knowledge is not consistent with the existing knowledge, learners will assimilate the existing knowledge and accommodate the new knowledge to create equilibrium (Piaget, 1971). Accordingly, if equilibrium is maintained, and knowledge is constructed and reconstructed in relation to the existing knowledge of learners and learning environment, cognitive growth will be created (Piaget, 1971).

Piaget (1926) claims that teachers need to assess learners' current level of cognitive strengths and weaknesses in order to apply appropriate teaching approaches. The instructional pedagogy also needs to be personalized to help learners have more opportunities to interact with others on learning tasks. Piaget views teachers as facilitators of student learning, their role being to instruct and encourage students to do their work and to learn from working with others. Some Piagetians (Murray, 1982; Damon, 1984; and Wadsworth, 1984) call for cooperative activities in schools because reciprocal interaction between learners on learning tasks brings more positive outcomes in students' learning 
achievement. It was argued by Heywood (1990) that "schools should be, among other things, places where important conversations can take place and that cooperative learning strategies help those conversations to happen in every classroom" (p.298). In addition, Slavin (1996) believes that students cannot learn much from others if there is no social interaction in learning. Slavin further insists that without social interaction in learning, there are no cognitive conflicts, non-correlative arguments, disequilibration, or higher-quality understanding. In the process of social interaction in learning, students can develop some necessary assistant learning skills as "a by-product of cooperative effort" (Damon, 1984, p.334). These skills, which include synthesis, analysis, argument, delegation, and deliberation, can be developed in conjunction with the cognitive aims of academic tasks. Moreover, if students participate in cooperative learning activities, they will be responsible, not only for their own learning, but also for others' learning.

Damon (1984) supports the viewpoint of cognitive development, and proposes a theoretical paradigm which combines the perspectives of Piaget and Vygotsky into peer co-operation, which explains why cooperative learning can improve student learning and achievement. This paradigm proposes "an educational program based on peer work" that can happen in cooperative learning activities with the following outcomes:

1) They expose inadequate or inappropriate reasoning, which results in disequilibrium than can lead to better understanding.

2) Through mutual feedback and debate, peers motivate one another to abandon misconceptions and search for better solutions.

3) The experience of peer communication can help a child master social processes, such as participation and argumentation, and cognitive processes, such as verification and criticism.

4) Collaboration between peers can provide a forum for discovery learning and can encourage creative thinking.

5) Peer interaction can introduce children to the process of generating ideas.

(Damon, 1984, p.335)

A major component in this paradigm is peer interaction in the process of learning and thinking. Damon (1984) advocates social interaction among peers because peer interaction is essential when students work together. In the process of teaching, teachers should introduce materials, situations and opportunities to students so that that they can find a new way of learning through peer interaction (Webb, 2008). Through peer interaction, socio-cognitive conflicts will happen and create cognitive disequilibrium which encourages speaking and reasoning ability (Slavin, 1990). Several studies (Mugny \& Doise, 1978; Perret-Clermont, 1980) support peer interaction, believing that it can help students work together on appropriate assignments effectively. From the developmental perspective, the effects of cooperative learning on student achievement would be largely or entirely due to the use of cooperative tasks. In this view, opportunities for students to discuss, argue, and present and hear one another's viewpoints are the critical element of cooperative learning with respect to student achievement (Slavin, 2011). The cognitive theories of Vygotsky and Piaget emphasize the practice of cooperative learning. The former encourages social interaction while the latter supports learners' active learning. Both are necessary to realize the practice of cooperative learning in a lively learning class. These theories can offer justification for the application of cooperative learning as they are implemented in this research study. Such theories are consistent with the principles of cooperative learning in which an interactive, cooperative and learner-centered approach in learning is emphasized. In this study, learning activities and interactive learning tasks requiring a lot of student talk will be, therefore, scheduled in the treatment group to help increase mutual interaction among students. It would be expected that students in the treatment group learn more from working with other group members.

Cognitive elaboration viewpoint

Another cognitive perspective relevant to an exploration of the value of cooperative group work, based on the notion of cognitive elaboration (explaining something more), has been identified by O'Donnell \& O'Kelly (1994) and O'Donnell (2000). This viewpoint stresses the effectiveness of elaboration in the process of learning and thinking, and that elaboration prepares the individual for cognitive re-structure and rehearsal in order to enhance learning tasks (Slavin, 2011). Research in cognitive psychology has long held that if information is to be retained in memory and related to information already in memory, the learner must engage in some sort of cognitive restructuring, or elaboration of the material (Wittrock, 1986). Another explanation may be that an effective technique of elaboration is required in almost all cooperative learning methods (Slavin, 2011). Elaboration involves adding new information to and reestablishing the available existing knowledge, resulting in the deeper processing of lesson content (Singhanayok \& Hooper, 1998; Iqbal, 2004). If students are given the opportunity to explain or clarify ideas, their learning will be more successful (Zakaria, Chin \& Daud, 2010). Elaboration not only improves students' learning when they are offered 
explanations but also enlarges their understanding when they give elaborated explanations to others (McKeachie, 1999). In addition, a significant benefit of receiving information from others is that it helps students have more opportunity to access information and observe learning strategies used by other students (Singhanayok \& Hooper, 1998). Research on peer tutoring has found benefits for the tutor as well as the tutee. In such methods, students take the roles of recaller or listener. They read a section of text, and then the recaller summarizes the information while the listener corrects any errors, fills in any omitted material, and helps think of ways both students can remember the main ideas (Slavin, 2011).

In a review of 19 studies on oral interaction in small groups, Webb (1989) reports that the "effectiveness of learning in groups depends on the level of elaboration of the explanation given ... the processes of mutual explaining and questioning are regarded as effective ways of elaboration" (p.757). He further discovered that students achieve more knowledge and skills from engaging in cooperative activities when they offer more explanations to others. O'Donnell (1996) found that students working on structured cooperative scripts can learn material or procedures better than students working alone. While both the recaller and the listener learned more than students working alone, the recaller learned more (O'Donnell \& Dansereau, 1992). This mirrors both the peer tutoring findings and the findings of Webb (2008), who discovered that the students who gained the most from cooperative activities were those who provided elaborated explanations to others. Studies of Reciprocal Teaching, in which students learn to formulate questions for each other, have generally supported its positive effects on student achievement and retention (O'Donnell, 2000; Rosenshine \& Meister, 1994). This perspective involves the nature and principles of cooperative learning in which learners work and learn from one another through reciprocal interaction and explanation. Consequently, students in the cooperative learning groups are expected to cooperate with other students in their groups on learning materials assigned, discuss these materials, complete their own assigned section of learning material, and then teach others in their group their part of the material. As a result of all of these activities, students are expected to gain knowledge effectively.

\subsection{Social learning theory}

The social learning theory, first introduced by Albert Bandura in 1971, bridges behavioral and cognitive learning theories by taking into account how imitable behaviors are affected by cognitive constructs, such as attention, retention, production and motivation. Bandura (1977), the prominent theorist of social learning theory, briefly illustrated that much learning occurs by observing, modeling and imitating models. The major premise of social learning theory is that learners can improve their knowledge and retention by observing and modeling the desired behaviors, attitudes and reactions of others, and that human thought processes are central to understanding personality (Schunk, 2007). Bandura (1977) argues that "behavior is learned symbolically through the central processing of response information before it is performed" (p.30). He further states that "most human behavior is learned observationally through modeling" and that from "observing others one forms an idea of how new behaviors are performed, and on later occasions this coded information serves as a guide for action" (p.22). To create the new behavior, learners will form an idea by observing a reproduction of the desired behavior. Learners learn more through the observation of models when they display new patterns of behavior (Schunk, 2007). According to social learning theory, most learning takes place in a social environment, in which learners obtain knowledge, rules, skills, strategies, beliefs, and attitudes by observing others (Schunk, 2007). This theory places human behavior within a framework of three reciprocal interactions: person, behavior, and environment (Schunk, 2007). These factors interact and influence one another. It is like a triangle, all three parts are needed to keep the triangle in place. Bandura (1986) reports that:

In social cognitive theory, people are neither driven by inner forces nor automatically shaped and controlled by the motivation, behavior, and development within a network of reciprocally interacting influences. Persons are in terms of a number of basic capabilities (p.6).

Bandura (1986) believes that not only does environment cause behavior, behavior causes environments as well, through reciprocal interaction. He argues that the development of the personality is the result of continuous reciprocal interaction between three components: the environment, behavior, and one's psychological processes. These interactions impact the learner's self-efficacy. Self-efficacy beliefs of learners determine their goals, and effort in the face of failure and setbacks (Bandura, 1997). One implication of this triadic model is that students' self-efficacy or belief in their own abilities will impact their learning, and the teacher telling a student that he or she can succeed (environment) will impact the student's outcome in learning (behavior) (Johnson, Daigle, Rustamov, 2010). In order for the modeling component to be a success, social learning theory focuses on four component processes, which influence observational learning, also known as modeling. The four variables that are involved in modeling are attention, retention, reproduction, and motivation. Learners must pay attention, be capable of retaining what they have 
observed, be able to translate the observation into action, and be motivated to imitate the observed action. According to Bandura (1977), learners can learn more by observing and modeling the behaviors of others if they are given opportunities to attend to and perceive the significant features of the modeled behaviors. He argues that the values of perceived activities influence the attention of observers. If learners perceive modeled activities and their outcomes to be significant and rewarding, learners will have greater attention (Schunk, 2007). He further argues that observation and modeling do not influence learners if they cannot remember or retain the observed behaviors through imagery models and/or verbal descriptions. If the observed behaviors are associated with images or verbal descriptions, it is easier for learners to recall the observed behaviors at a later time. Bandura (1977) suggests that the retention of modeled information requires several cognitive activities such as organization, rehearsal, coding, and transformation. All of these activities can help learners store the modeled information in their memory for a long time (Schunk, 2007). Learners are also required to have the ability to be able to reproduce the observed information to actual information. Under production, which involves translating visual and symbolic conceptions of modeled events into overt behaviors, learners acquire a rough approximation of a complex skill (Bandura, 1977). A person must possess the capabilities necessary to complete the task. In addition, learning would be effective if learners have reasons to observe and imitate the actions of others. According to Schunk (2007), learners will have the motivation to observe and model the behaviors of others when they believe that the modeled behaviors can result in rewarding outcomes. The modeled behavior is not effectively adopted by learners if this behavior results in unrewarding or punishing effects (Johnson et al., 2010).

The social learning theory connects to cognitive and behavior learning theories, which also emphasize the central role of social learning by taking into account how imitable behaviors are affected by cognitive constructs, such as attention, retention, and motivation (Johnson et al., 2010). Reciprocal interactions among the students' personal factors, environmental variables, and behaviors are important constructs found in the practice of cooperative learning (Schunk, 2007; Johnson et al., 2010). Since social learning theory states that people learn more by observing and imitating the desired behaviors of others, a strong connection has been found between this theory and the practice of cooperative learning. Consequently, social behavior and the actions of effective learners in the cooperative learning groups are expected to be modeled and adopted by other students through reciprocal determinism, or the interaction between observed behaviors, cognitive factors, and external environments.

\subsection{Constructivist learning theory}

Cooperative learning is a student-centered learning method; therefore, it ties outcomes with the constructivist learning theory in which "learners are in control of constructing their own meaning in an active way" (Almala, 2005, p.10). To date, the constructivist theory has made a significant contribution to the student-centered learning approach (Yager, 1991; Lueddeke, 1999). This theory incorporates notions from the works of Piaget (1926), Vygotsky (1978) and Bandura (1977), as discussed in the previous section. Originating from philosophy, constructivist theory is effectively used in several areas such as sociology, anthropology and cognitive and educational psychology (Bruner, 1966). In the $18^{\text {th }}$ century, Giambattista Vico, an Italian philosopher of the constructivist learning theory, defined knowledge as a "cognitive structure of a person so that to know something is to know how to create" (Glaserfeld, 1989, p.11). Vico argues that a person knows something clearly only when he or she can explain it (Yager, 2000). To clarify this notion, Immanuel Kant (Yager, 1991) highlights that learners cannot be persons who receive information passively. Dewey (1972) also sees education as a process of restructuring knowledge by reflecting thoughts through the growth of current knowledge of learners. He believes that knowledge is not achieved or granted by learners, but constructed through their interaction with the environment, to create their own meaningful knowledge. Learning is a social process in which knowledge is constructed by learners in a social context and then they appropriate it (Brooks \& Brooks, 1999). Therefore, one of the expectations for students involved in the treatment group in this study is that they are encouraged to play the role of active constructors of knowledge, and they may learn more when they are in control of constructing their own meaningful knowledge through reciprocal interaction among students on interactive learning tasks.

Constructivist proponents believe that "learners are active organisms seeking meaning" (Driscoll, 2000, p.376). If the traditional perspective of education views learning as the process of direct provision of knowledge from teachers to students, the constructivist perspective views learning as a process in which students are active in constructing their knowledge (Huang, 2006). In the process of learning, students actively develop and enlarge their knowledge through observation, reflection, experimentation, discovery and especially, social interaction (Brooks \& Brooks, 1999). In the constructivist learning environment, students must be active, social and creative persons (Phillips, 1995) because they are considered constructors of knowledge, not passive receivers of knowledge (Glaserfeld, 1989). Almala (2005) proposes that students are enabled to "use knowledge in many different settings to make the learning itself as real-life as possible" (p.10) In addition, teachers are encouraged to play the role of facilitators of student learning in the 
constructivist learning environment rather than dispensers of knowledge as in the traditional learning environment (Almala, 2005). Accordingly, teachers as facilitators are essential to the success of students in the process of learning because "constructivist lessons are typically more student-centered than traditional lessons" (Mibrandt, Felts, Richards, \& Abghari, 2004, p.24). Marlow \& Page (2005) contrast constructivist learning with traditional learning in four basic ways: (1) "constructivist learning is constructing knowledge, not receiving knowledge"; (2) "constructivist learning is understanding and applying, not retention"; (3) "constructivist learning is thinking and analyzing, not accumulating and memorizing"; and (4) "constructivist learning is dynamic, not passive" (p.7). The effectiveness of traditional education is that students can receive a large amount of information from their teachers in a short time, but the rapid speed of distribution does not ensure an in-depth understanding for the receivers (Marlow \& Page, 2005). In contrast, in constructivist education, in-depth understanding is the focus, not recall or repetition. Such understanding may be shown by raising a problem, summarizing a problem, and applying the solution to that problem to other situations. In contrast to the higher level thinking emphasized in the constructivist classrooms, a large amount of information is memorized by learners in traditional classrooms (Huang, 2006). In the constructivist learning environment, students can approach a point at which information is meaningful to them, by researching, checking, discovering and analyzing learning issues (Huang, 2006). In-depth comprehension and understanding of students and their long-term retention of knowledge will be improved if students find their own answers, and discover solutions to problems (Dewey, 1972; Shachar \& Sharan, 1994; Johnson \& Johnson, 2008). From the constructivist notion, Bruner (1966) identifies the four key features of a theory of instruction as follows:

i) the experiences which most effectively implant in the individual a predisposition toward learning - learning in general or a particular type of learning;

ii) the ways in which a body of knowledge should be structured so that it can be most readily grasped by the learner;

iii) the most effective sequences in which to present the materials to be learned; and

iv) the nature and pacing of rewards and punishment in the process of learning and teaching. (Bruner, 1966, p.40-41).

Together with constructivist learning, these four features of instruction are consistent with the cooperative learning principles. Constructivist learning theory focuses on how learners learn, not on what they learn; therefore, it can be applied to the practice of cooperative learning (Almala, 2005; Dat-Tran, 2007). If learning materials are well designed, this learning theory will offer "the necessary theoretical support" for applying cooperative learning in the class effectively (Mibrandt et al., 2004, p.24). Therefore, students in cooperative learning groups are expected to learn more when they are in control of constructing their own knowledge through reciprocal interaction with their group members.

\section{Conclusion}

An exploration of theoretical perspectives shows that all provide rational, reasonable and empirical support for the superiority of cooperative learning. Each of these perspectives contributes to an understanding of cooperative learning in terms of improving academic, social and psychological aspects. These perspectives are considered the basic theoretical foundation for the application of cooperative learning in the classrooms because they complement one another to support the effectiveness of cooperative learning. As a result of this review, all of these theoretical perspectives emphasize the important role of reciprocal interaction among participants in constructing knowledge. This corresponds to the nature of cooperative learning, in which students are required to interact together on learning tasks to obtain a shared goal. From such theoretical perspectives, students in the cooperative learning group learn more because they were active agents in constructing their own knowledge through interaction with their peers in groups and with their teacher.

\section{References}

Almala, A. H. (2005). A Constructivist Conceptual Framework for a Quality e-Learning Environment. Distance Learning, 2(5), 9-12.

Archer-Kath, J., Johnson, D. W., \& Johnson, R. (1994). Individual versus group feedback in cooperative groups. Journal of Social Psychology, 134(5), 681-694. http://dx.doi.org/10.1080/00224545.1994.9922999

Aronson, E., Blaney, N., Stepan, C., Sikes, J., \& Snapp, N. (1978). The jigsaw classroom (2 ${ }^{\text {nd }}$ ed.). Beverley Hills, CA: Sage. 
Ballantine, J., \& Larres, P. M. (2007). Cooperative learning: a pedagogy to improve students' generic skills? Education and Training, 49(2), 127-137. http://dx.doi.org/10.1108/00400910710739487

Bandura, A. (1977). Social Learning Theory ( $3^{\text {rd }}$ ed.). Englewood Cliffs, NJ: Prentice Hall Regents.

Bandura, A. (1986). Social foundations of thought and action: a social cognitive theory (1 $1^{\text {st }}$ ed.). Englewood Cliffs: Prentice-Hall.

Bandura, A. (1997). Self-efficacy: The exercise of control (1 $1^{\text {st }}$ ed.). New York: Freeman \& Company.

Beck, L. L., \& Chizhik, A. W. (2008). An experimental study of cooperative learning in CS1.In Proceedings of the 39th SIGCSE technical symposium on Computer science education(pp. 205-209). New York: ACM. http://dx.doi.org/10.1145/1352135.1352208

Brooks, M. G., \& Brooks, J. G. (1999). The Courage to be constructivist. Educational Leadership, 57(3), 18-24.

Bruner, J. (1966). Toward a theory of instruction (1 $1^{\text {st }}$ ed.). Cambridge, MA: Harvard University Press.

Crawford, J., \& Haaland, G. (1972). Predecisional information seeking and subsequent conformity in the social influence process. Journal of Personality and Social Psychology, 23(1), 112-119. http://dx.doi.org/10.1037/h0032870

Crombag, H. (1966). Cooperation and competition in means interdependence triads: A replication. Journal of Personality and Social Psychology, 4 (6), 692-695. http://dx.doi.org/10.1037/h0023994

Damon, W. (1984). Peer education: the untapped potential. Journal of Applied Developmental Psychology, 5(4), 331-343. http://dx.doi.org/10.1016/0193-3973(84)90006-6

Dat-Tran, V. (2007). Constructivist Learning Theory and the Process of Forum Teaching. Journal of Teaching and Learning, 7(2), 57-60.

Deutsch, M. (1949). A theory of cooperation and competition. Human Relations, 2(2), 129-152. http://dx.doi.org/10.1177/001872674900200204

Dewey, J. (1991). Experience and education. In A. Boydston (Ed.), Johnson Dewey: The later works, 1938-1939 (pp. 1-62). Carbondale, II: Siu Press.

Driscoll, M. P. (2000). Psychology of learning for instruction (2nd ed.). Boston: Allyan \& Bacon.

Gerard, H., Wilhelmy, R., \& Conolley, E. (1965). Conformity and group size. Journal of Personality and Social Psychology, 8(1), 79-82. http://dx.doi.org/10.1037/h0025325

Gillies, R. (2003). Structuring cooperative group work in classrooms. International Journal of Educational Research, 39(1), 35-49. http://dx.doi.org/10.1016/S0883-0355(03)00072-7

Glaserfeld, E. V. (1989). Cognition, construction of knowledge, and teaching( $1^{\text {st }}$ ed.). Washington, DC: National Science Foundation.

Harkins, S., \& Petty, R. (1982). The effects of task difficulty and task uniqueness on social loafing. Journal of Personality and Social Psychology, 43(6), 1214-1229. http://dx.doi.org/10.1037/0022-3514.43.6.1214

Hassard, J. (1990). Science experiences: Cooperative learning and the teaching of science. Menlo Park, CA: Addition-Wesley.

Heywood, P. (1990). Winning teachers! In M. Brubacher, R. Payne \& K. Rickett (Eds.), Perspectives on small group learning (pp. 284-299). Ontario: Rubicon Publishing Inc.

Hooper, S., Ward, T., Hannafin, M., \& Clark, H. (1989). The effects of aptitude composition on achievement during small group learning. Journal of Computer-Based Instruction, 16(3), 102-109.

Horney, K. (1937). The Neurotic Personality of our Time (5 $5^{\text {th }}$ d.). New York: Norton.

Huang, G. H. (2006). Informal Forum: Fostering Active Learning in A Teacher Preparation Program. Education, 127(1), 31-38.

Hwong, N., Caswell, A., Johnson, D. W., \& Johnson, R. (1993). Effects of cooperative and individualistic on prospective elementary teachers' music achievements and attitudes. Journal of Social Psychology, 133(1), 53-64. http://dx.doi.org/10.1080/00224545.1993.9712118

Jensen, M., Moore, R., \& Hatch, J. (2002). Cooperative Learning - Part I: Cooperative Quizzes. The American Biology Teacher, 64(1), 29-34. http://dx.doi.org/10.1662/0002-7685(2002)064[0029:CLPICQ]2.0.CO;2 
Johnson, A. W., \& Johnson, R. (2002). Cooperative Learning Methods: A meta-analysis. Journal of Research in Education, 12(1), 5-14.

Johnson, C., Daigle, P., \& Rustamov, I. (2010). Bandura's Social Learning Theory Applied to a "How-to" Expository Writing $\quad$ Piece. [Online] Available: http://uhaweb.hartford.edu/SMITHJOHN/EDT665/EDT-FINALDEC132010\%5B1\%5D.pdf

Johnson, D. W. (2003). Social Interdependence: The Interrelationships among theory, research, and practice. American Psychologist, 58(11), 931-945. http://dx.doi.org/10.1037/0003-066X.58.11.934

Johnson, D. W., \& Johnson, F. (2006). Joining Together: Group Theory and group skills ( $7^{\text {th }}$ ed.). Boston: Allyn \& Bacon.

Johnson, D. W., \& Johnson, R. (1981). Effects of cooperative and individualistic learning experiences on interethics interaction. Journal of Educational Psychology, 73(3), 454-459. http://dx.doi.org/10.1037/0022-0663.73.3.444

Johnson, D. W., \& Johnson, R. (2005). New Developments in Social Interdependence Theory. Genetic, Social, \& General Psychology Monographs, 131(4), 285-358. http://dx.doi.org/10.3200/MONO.131.4.285-358

Johnson, D. W., \& Johnson, R. (2007). Creative controversy: Academic conflict in the classroom (4 ${ }^{\text {th }}$ ed.). Edina, MN: Interaction Book Company.

Johnson, D. W., \& Johnson, R. T. (1974). Instructional Goal Structure: Cooperative, Competitive, or Individualistic. Review of Educational Research, 44(2), 213-240. http://dx.doi.org/10.3102/00346543044002213

Johnson, D. W., \& Johnson, R. T. (1989). Cooperation and Competition: Theory and Practice. Edina, MN: International Book Company.

Johnson, D. W., \& Johnson, R. T. (1990a). Cooperative Classrooms. In M. Brubacher, R. Payne \& K. Rickett (Eds.), Perspectives on Small Group Learning: Theory and Practice (pp. 119-131). Ontario: Rubicon Publishing Inc.

Johnson, D. W., \& Johnson, R. T. (1990b). Social skills for successful groups work. In R. S. Brandt (Ed.), Readings from educational leadership on cooperative learning and the collaborative school (pp. 51-54): Association for Supervision and Curriculum Development, 125 North West Street, Alexandria.

Johnson, D. W., \& Johnson, R. T. (1990c). What is Cooperative Learning? In M. Brubacher, R. Payne \& K. Rickett (Eds.), Perspectives on Small Group Learning: Theory \& Practice (pp. 68-79). Ontario: Rubicon Publishing Inc.

Johnson, D. W., \& Johnson, R. T. (1994a). Learning Together. In S. Sharan (Ed.), Handbook of Cooperative Learning Methods (pp. 51-65). London: Greenwood Press.

Johnson, D. W., \& Johnson, R. T. (2008). Social Interdependence Theory and Cooperative Learning: The Teacher's Role. In R. M. Gillies, A. Ashman \& J. Terwel (Eds.), Teacher's Role in Implementing Cooperative Learning in the Classroom (pp. 9-37). New York, U.S.A: Springer. http://dx.doi.org/10.1007/978-0-387-70892-8_1

Johnson, D. W., \& Johnson, R. T. (2009). An Educational Psychology Success Story: Social Interdependence Theory and Cooperative Learning. Educational Researcher, 385(5), 365-379. http://dx.doi.org/10.3102/0013189X09339057

Johnson, D. W., \& Johnson, T. R. (1999). Cooperative Learning and Achievement. In D. Kluge, S. McGuire, D. Johnson \& R. Johnson (Eds.), Cooperative Learning: JALT Applied Materials (pp. 23-37). New York: Greenwood Press, Inc.

Johnson, D. W., \& Noonan, P. (1972). Effects of acceptance and reciprocation of self-disclosures on the development of trust. Journal of Counseling Psychology, 19(5), 411-416. http://dx.doi.org/10.1037/h0033163

Johnson, D. W., Johnson, R. T., \& Houlubec, E. (1994). The new circles of learning: Cooperation in the classroom and school ( $3^{\text {rd }}$ ed.). Alexandre Virginia: Association for Supervision and Curriculum Development.

Johnson, D. W., Johnson, R. T., \& Stanne, M. B. (2000). Cooperative Learning Methods: A Meta - Analysis [Online] Available: http://www.co-operation.org/pages/cl-methods.html

Johnson, D. W., Johnson, R., Stanne, M., \& Garibaldi, A. (1990). The impact of leader and member group processing on achievement in cooperative groups. Journal of Social Psychology, 130, 507-516. http://dx.doi.org/10.1080/00224545.1990.9924613

Johnson, D., W, \& Johnson, R. (2005). New Developments in Social Interdependence Theory. Genetic, Social, \& General Psychology Monographs, 131(4), 285-358. http://dx.doi.org/10.3200/MONO.131.4.285-358 
Johnson, D., W. (2009). Reaching out: Interpersonal effectiveness and self-actualization (10 ${ }^{\text {th }}$ ed.). Boston: Allyn \& Bacon.

Johnson, R. T., \& Johnson, D. W. (1994b). Overview of Cooperative Learning. In J. Thousand, A. Villa \& A. Nevin (Eds.), Creativity and Collaborative Learning (pp. 31-44): Brookes Press, Baltimore.

Johnson, W. D., \& Johnson, T. R. (1994c). Learning together and alone: cooperation, competition, and individualization ( $4^{\text {th }}$ ed.). Englewood Cliffs, N.J: Prentice-Hall.

Jolliffe, W. (2007). Cooperative learning in the classroom: Putting it into Practice (1 ${ }^{\text {st }}$ ed.). Thousand Oaks: Paul Chapman Publishing.

Kagan, S. (1985). Dimentions of Cooperative Classroom Structures. In R. E. Slavin, S. Sharan, S. Kagan, R. Hertz-Lazarowits, C. Webb \& R. Schmuck (Eds.), Learning to Cooperate, Cooperating to Learn (pp. 67-96). New York: Plenum Press. http://dx.doi.org/10.1007/978-1-4899-3650-9_3

Kerr, N. (1989). Illusions of efficacy: The effects of group size on perceived efficacy in social dilemmas. Journal of Experimental Social Psychology, 25, 297-313. http://dx.doi.org/10.1016/0022-1031(89)90024-3

Kerr, N., \& Bruun, S. (1983). The dispensability of member effort and group motivation losses: Free-rider effects. Journal of Personality and Social Psychology, 44, 78-94. http://dx.doi.org/10.1037/0022-3514.44.1.78

Killen, R. (2007). Effective Teaching Strategies: Lessons from Research and Practice ( $4^{\text {th }}$ ed.). Melbourne: Thompson Social Sciences Press.

Knight, P. G., \& Bohlmeyer, M. E. (1990). Cooperative Learning and Achievement: Methods for Assessing Causal Mechanisms. In S. Sharan (Ed.), Cooperative Learning: Theory and Practice (pp. 1-22). New York: Greenwood Press, Inc.

Kose, S., Sahin, A., Ergun, A., \& Gezer, K. (2010). The effects of cooperative learning experience on eighth grade students' achievement and attitude toward science. Education, 131(1), 169-180.

Lew, M., Mesch, D., Johnson, D. W., \& Johnson, R. (1986). Positive interdependence, academic and collaborative-skills group contingencies and isolated students. American Education Research Journal, 23, 476-488. http://dx.doi.org/10.3102/00028312023003476

Levin, K. (1948). Resolving Social Conflicts. New York: Harper.

Liang, T. (2002). Implementing Cooperative Learning in EFL Teaching: Process and Effects(Doctoral dissertation, National Taiwan Normal University). [Online] Available: http://www.asian-efl-journal.com/Thesis_Liang_Tsailing.pdf (July 17, 2009)

Lotan, R. A. (2004). Stepping into group works. In E. G. Cohen, C. M. Brody \& M. Sapon-shevin (Eds.), Teaching cooperative learning: The challenge for teacher education (pp.167-182). New York: State University of New York Press.

Lueddeke, G. R. (1999). Toward a Constructivist Framework for Guiding Change and Innovation in Higher Education. Journal of Higher Education, 70, 235-260. http://dx.doi.org/10.2307/2649196

Marlow, B. A., \& Page, M. L. (2005). Creating and sustaining the constructivist classroom ( $2^{\text {nd }}$ ed.): Thousand Oaks, CA: Corwin Press.

McKeachie, W. (1999). Teaching Tips: Strategies, Research and Theory of College and University Teachers (10 ${ }^{\text {th }}$ ed.): Houghton Mifflin, Boston M.A, USA.

Mesch, D., Johnson, D. W., \& Johnson, R. (1988). Impact of positive interdependence and academic group contigencies on achievement. Journal of Social Psychology, 128, 345-352. http://dx.doi.org/10.1080/00224545.1988.9713751

Messick, D., \& Brewer, M. (1983). Solving social dilemmas: A review. Review of Personality and Social Psychology, 4, 11-44.

Milbrandt, M. K., Felts, J., Richards, B., \& Abghari, N. (2004). Teaching-to-Learn: A Constructivist Approach to Shared Responsibility. Art Education, 57(5), 19-33.

Montagu, A. (1966). On Being Human (2 $2^{\text {nd }}$ ed.): New York: Hawthorn.

Mugny, G., \& Doise, W. (1978). Socio-cognitive conflict and structurization of individual collective performances. European Journal of Social Psychology, 8, 181-192. http://dx.doi.org/10.1002/ejsp.2420080204 
Murray, F. B. (1982). Teaching through social conflict. Contemporary Educational Psychology, 7, 257-271. http://dx.doi.org/10.1016/0361-476X(82)90031-5

O'Donnell, A. M. (1996). The effects of explicit incentives on scripted and unscripted cooperation. Journal of Educational Psychology, 88(1), 74-86. http://dx.doi.org/10.1037/0022-0663.88.1.74

O'Donnell, A. M. (2000). Interactive effects of prior knowledge and material format on cooperative teaching. Journal of Experimental Education, 68(2), 101-108. http://dx.doi.org/10.1080/00220970009598497

O'Donnell, A. M., \& Dansereau, D. F. (1992). Scripted cooperation in student dyads: A method for analyzing and enhancing academic learning and performance. In R. Hertz-Lazarowitz \& N. Miller (Eds.), Interaction in cooperative groups: The theoretical anatomy of group learning (pp. 120-144). New York: Cambridge University Press.

O'Donnell, A. M., \& O'Kelley, J. (1994). Learning from peers: Beyond the rhetoric of positive results. Educational Psychology Review, 6, 321-349. http://dx.doi.org/10.1007/BF02213419

Perret-Clermont, A.-N. (1980). Social interaction and cognitive development in children: New York: Academic Press.

Phillips, D. C. (1995). The good, the bad, and the ugly: The many faces of constructivism. Educational Researcher, 24(7), 5-12. http://dx.doi.org/10.3102/0013189X024007005

Piaget, J. (1926). The language and thought of the child (1st ed.). New York: Harcourt Brace.

Piaget, J. (1971). Biology and knowledge: An essay on the relation between organic regulations and cognitive processes. Chicago: University of Chicago Press.

Putnam, J., Rynders, J., Johnson, R., \& Johnson, D. W. (1989). Collaborative skills instruction for promoting positive interactions between mentally handicapped and nonhandicaped children. Exceptional Children, 55, 550-557.

Robertson, L. (1990). Cooperative Learning A La Clip. In M. Brubacher, R. Payne \& K. Rickett (Eds.), Perspectives on Small Group Learning (pp. 185-201). Ontario: Rubicon Publishing Inc.

Rosenshine, B., \& Meister, C. (1994). Reciprocal teaching: A review of research. Review of Educational Research, 64, 4788-5306. http://dx.doi.org/10.3102/00346543064004479

Ryan, R. (1982). Control and information in the intrapersonal sphere: An extension of cognitive evaluation theory. Journal of Personality and Social Psychology, 43, 450-461. http://dx.doi.org/10.1037/0022-3514.43.3.450

Schunk, D. H. (2007). Learning theories: An Educational Perspective (4th ed.). Upper Saddle River, NJ: Pearson Education.

Shachar, H., \& Sharan, S. (1994). Talking, Relating, and Achieving: Effects of Cooperative Learning and Whole-Class Instruction. Cognition and Instruction, 12(4), 313-353. http://dx.doi.org/10.1207/s1532690xci1204_2

Sharan, S. (1990). Cooperative learning: A Perspective on Research and Practice. In P. Kussell, R. Hertz-Lazarowits, Y. Bejarano, S. Raviv \& Y. Sharan (Eds.), Cooperative Learning in the Classroom: Research in Desegregated Schools (pp. 285-300). New Jersey: Lawrence Erlbaum Associates, Inc.

Sharan, S. (1994). Cooperative learning and the teacher. In S. Sharan (Ed.), Handbook of cooperative learning methods (pp. 51-64). London: Greenwood Press.

Singhanayok, C., \& Hooper, S. (1998). The effects of cooperative learning and learner control on students' achievement, option selections, and attitudes. Educational Technology Research and Development, 46(2), 17-36. http://dx.doi.org/10.1007/BF02299787

Skinner, B. (1968). The technology of teaching. New York: Appleton-Century-Crofts.

Slavin, R. E. (1990). Cooperative learning: Theory, research, and practice ( $2^{\text {nd }}$ ed.). New Jersey: Prentice Hall.

Slavin, R. E. (1996). Research on co - operative learning and achievement: What we know, what we need to know. Contemporary Educational Psychology, 21(4), 43-69. http://dx.doi.org/10.1006/ceps.1996.0004

Slavin, R. E. (2011). Instruction Based on Cooperative Learning. In R. E. Mayer \& P. A. Alexander (Eds.), Handbook of Research on Learning and Instruction (pp. 344-360). New York: Taylor \& Francis.

Thomas, E. J. (1957). Effects of facilitate role interdependence on group functioning. Human Relations, 10, 347-366. http://dx.doi.org/10.1177/001872675701000404 
Vygotsky, L. S. (1978). Mind in society: the development of higher psychological processes. Cambrigde: Harward University Press.

Wadsworth, B. J. (1984). Piaget's theory of cognitive and affective development. New York: Longman.

Webb, N. M. (1989). Peer interaction and learning in small groups. International Journal of Educational Research, 13, 21-39. http://dx.doi.org/10.1016/0883-0355(89)90014-1

Webb, N. M. (2008). Learning in small groups. In T. L. Good (Ed.), 21 st Century education: A reference handbook (pp. 203-211). Los Angeles: Sage.

Webb, N., \& Cullian, L. (1983). Group interaction and achievement in small groups: Stability over time. American Education Research Journal, 20(3), 411-423. http://dx.doi.org/10.3102/00028312020003411

Wicklund, R., \& Brehm, J. (1976). Perspectives on cognitive dissonance. Hillsdale, NJ: Erlbaum.

Wittrock, M. C. (1986). Students' thought processes. In M. C. Wittrock (Ed.), Handbook of research on teaching (PP.297-314). New York: Macmillan.

Yager, R. (1991). The constructivist learning model, towards real reform in science education. The Science Teacher, $58(2), 52-57$.

Yager, R. E. (2000). The Constructivist Learning Model. The Science Teacher, 67(1), 44-45.

Yager, S., Johnson, R., Johnson, D. W., \& Snider, B. (1986). The impact of group processing on achievement in cooperative learning groups. Journal of Social Psychology, 126, 389-397. http://dx.doi.org/10.1080/00224545.1986.9713601

Yamarik, S. (2007). Does cooperative learning improve student learning outcomes? (Research in Economic Education)(Report). The Journal of Economic Education, 38(3), 259-277. http://dx.doi.org/10.3200/JECE.38.3.259-277

Zakaria, E., Chin, L. C., \& Daud, Y. (2010). The Effects of Cooperative Learning on Students' Mathematics Achievement and Attitude toward Mathematics. Journal of Social Sciences, 6(2), 272-275. http://dx.doi.org/10.3844/jssp.2010.272.275 